\title{
Impact of Humidification and Nebulization During Expiratory Limb Protection: An Experimental Bench Study
}

\author{
Alexandre Tonnelier MD, François Lellouche MD PhD, \\ Pierre Alexandre Bouchard RRT, and Erwan L'Her MD PhD
}

\begin{abstract}
BACKGROUND: Different filtering devices are used during mechanical ventilation to avoid dysfunction of flow and pressure transducers or for airborne microorganisms containment. Water condensates, resulting from the use of humidifiers, but also residual nebulization particles may have a major influence on expiratory limb resistance. OBJECTIVES: To evaluate the influence of nebulization and active humidification on the resistance of expiratory filters. METHODS: A respiratory system analog was constructed using a test lung, an ICU ventilator, heated humidifiers, and a piezoelectric nebulizer. Humidifiers were connected to different types of circuits (unheated, mono-heated, new-generation and old-generation bi-heated). Five filter types were evaluated: electrostatic, heat-and-moisture exchanger, standard, specific, and internal heated high-efficiency particulate air [HEPA] filter. Baseline characteristics were obtained from each dry filter. Differential pressure measurements were carried out after 24 hours of continuous in vitro use for each condition, and after 24 hours of use with an old-generation bi-heated circuit without nebulization. RESULTS: While using unheated circuits, measurements had to be interrupted before 24 hours for all the filtering devices except the internal heated HEPA filter. The heat-and-moisture exchangers occluded before 24 hours with the unheated and mono-heated circuits. The circuit type, nebulization practice, and duration of use did not influence the internal heated HEPA filter resistance. CONCLUSION: Expiratory limb filtration is likely to induce several major adverse events. Expiratory filter resistance increase is due mainly to the humidification circuit type, rather than to nebulization. If filtration is mandatory while using an unheated circuit, a dedicated filter should be used for $\leq \mathbf{2 4}$ hours, or a heated HEPA for a longer duration. Key words: expiratory limb protection; filters; humidification; mechanical ventilation; nebulization. [Respir Care 2013;58(8):1315-1322. () 2013 Daedalus Enterprises]
\end{abstract}

\section{Introduction}

When performing nebulization under mechanical ventilation, filtering of expiratory gases is mandatory to prevent

Dr Tonnelier and Dr L'Her are affiliated with Réanimation Médicale et Urgences Adultes, Centre Hospitalier Régional Universitaire de la Cavale Blanche, Brest, France; with the Faculté de Médecine et des Sciences de la Santé, Université de Bretagne Occidentale, Brest, France; and with Université Européenne de Bretagne, Rennes, France. Dr Lellouche, Mr Bouchard, and Dr L'Her are affiliated with Institut de Cardiologie et de Pneumologie de Québec, Université Laval, Québec City, Québec, Canada. Dr L'Her is also affiliated with Le Laboratoire de Traitement de l'Information Médicale, Institut National de la Santé et de la Recherche Médicale, Unité Mixte de Recherche Centre Hospitalier Régional Universitaire Brest, Université de Bretagne Occidentale, Brest, France; and with Chaire de Recherche en Médecine d'Urgence Hôtel Dieu de Lévis, Université Laval, Québec City, Québec, Canada. dysfunction of flow and pressure transducers. ${ }^{1-3}$ Such a problem has already been identified with the administration of ribavirin during mechanical ventilation back in the 1980s, for pediatric patients with bronchiolitis due to respiratory syncytial virus. ${ }^{4}$ Whereas there have been ad-

\footnotetext{
This research was partly supported by a grant from Maquet to the Chaire de Recherche en Médecine d'Urgence, Hôtel Dieu de Lévis, Université Laval, Québec City, Québec, Canada. The authors have disclosed no conflicts of interest.

Correspondence: Erwan L'Her MD PhD, Réanimation Médicale, Centre Hospitalier Régional Universitaire de la Cavale Blanche, 29609 Brest, France. E-mail: erwan.lher@chu-brest.fr.
}

DOI: $10.4187 /$ respcare. 01785 
vances in humidifier design and efficiency, and the arsenal of aerosolized drugs and indications has expanded, this topic is relevant to intensive care and mechanical ventilation today. Expiratory limb filtration might also be considered to prevent cross contamination in case of airborne contaminants (eg, tuberculosis, flu pandemic, severe acute respiratory syndrome $[\mathrm{SARS}])^{5-9}$ Few recommendations exist to help clinicians choose the filtering device in such cases. ${ }^{3,8,9}$ Moreover, manufacturers usually recommend a daily replacement of the device, thus leading to potential healthcare worker exposure to aero-contaminants and inducing recurrent depressurization of the circuit and alveolar derecruitment. Problems related to the use of filters with nebulized drugs are another part of the problem. ${ }^{3,10}$ The performance of filters depends not only on the type, and bacterial or viral filtration efficiency may be inadequate or highly misleading. ${ }^{1,9}$

Nebulization and humidification tend to be similar processes in that both are methods to convert liquid (medication or water) into mist or vapor for humidification and particles that remain suspended within a gas for a period of time for nebulization, and both can be inhaled into the lower respiratory tract. If humidification provides warm water vapor in a continuous process to prevent damage to the airway lining of the tracheobronchial tree, nebulization produces cool mist that is administered intermittently. In case of a decrease in temperature, condensation and formation of droplets will occur while using a humidifier. Humidification of the inspiratory gases by a heated humidifier may therefore have a great impact on the mechanical properties of expiratory filters, thus modifying filtration properties and leading to potentially lethal ventilator dysfunctions. ${ }^{10-17}$ This effect may be enhanced by temperature variations within the circuit, thus generating condensation. Whatever the device used, nebulization particles are usually of higher size than water mist and may thus increase saturation of filters, especially in case of "sticky" buffer like colistin or several other pharmaceutical drugs. ${ }^{18}$ However, whereas nebulizers are usually delivered intermittently, humidification is provided continuously; it could be hypothesized that humidification may have a more prominent effect.

The aims of this experimental bench test study were to evaluate the consequences of active humidification on the performance of different types of breathing filters, considering the type of circuit used, and to evaluate the impact of nebulization on these devices.

\section{Methods}

\section{Artificial Respiratory System}

We used an ICU ventilator (Evita 2 Dura, Dräger, Lübeck, Germany) for most measurements. We used an Avea

\section{QUICK LOOK}

\section{Current knowledge}

A filter in the expiratory limb of the ventilator circuit protects volume and pressure transducers from water vapor and aerosolized medications, but accumulated moisture in the filter can increase the expiratory resistance and cause complications due to incomplete exhalation.

\section{What this paper contributes to our knowledge}

Increased expiratory resistance was primarily related to the type of humidification and type of filter. The greatest expiratory resistance increase was with heated humidifier and unheated circuit. A heated expiratory filter gave the greatest protection from increased expiratory resistance.

(Viasys Healthcare/CareFusion, San Diego, California) for evaluation of the internal heated expiratory filter. Respiratory parameters were as follows: continuous mandatory ventilation, breathing frequency 18 breaths/min, tidal volume $600 \mathrm{~mL}$, inspiratory time $0.8 \mathrm{~s}$, inspiratory flow $60 \mathrm{~L} / \mathrm{min}, \mathrm{F}_{\mathrm{IO}_{2}} 0.21$, PEEP $5 \mathrm{~cm} \mathrm{H} \mathrm{H}_{2} \mathrm{O}$.

We used 2 models of heated humidifier (MR850 and MR460, Fisher \& Paykel, Auckland, New Zealand). We used one model of piezoelectric nebulizer (Aeroneb Pro, Aerogen, Mountain View, California) after the Y-piece on the expiratory limb, to maximize the impact of nebulized drug (colimycine 6 million units $/ 24 \mathrm{~h}$, in $4 \mathrm{~mL}$ saline) on the filters.

We used a standard test lung (test lung 190, Maquet Critical Care, Sölna, Sweden) with a volume of $1 \mathrm{~L}$, compliance of $30 \mathrm{~mL} / \mathrm{cm} \mathrm{H}_{2} \mathrm{O}$, and resistance of $20 \mathrm{~cm} \mathrm{H}_{2} \mathrm{O} / \mathrm{L} / \mathrm{s}$.

\section{Expiratory Filters}

The tested filters were placed on the expiratory limb, at the ventilator input. Five different types were tested: electrostatic (Anest-Guard, Gibeck-Teleflex, High Wycombe, England, internal dead space $50 \mathrm{~mL}$ ); standard high efficiency particulate air (HEPA) filter (Iso-Gard HEPA Light, Gibeck-Teleflex, High Wycombe, England, dead space $80 \mathrm{~mL}$ ); specific HEPA, conceived for expiratory limb protection (Servo Duo Guard, Maquet, Sölna, Sweden, dead space $170 \mathrm{~mL}$ ); heat and moisture exchanger (HME) (Humid-Vent Compact, Gibeck-Teleflex, High Wycombe, England, dead space $38 \mathrm{~mL}$ ); internal heated HEPA filter of the Avea ventilator. The baseline characteristics of these filters are provided within Table 1. 
Table 1. Filters Characteristics*

\begin{tabular}{|c|c|c|c|c|}
\hline Filter & Type & $\begin{array}{c}\text { Internal } \\
\text { Volume } \\
(\mathrm{mL})\end{array}$ & $\begin{array}{l}\text { Flow } \\
\text { Resistance } \\
\text { at } 60 \mathrm{~L} / \mathrm{min} \\
\left(\mathrm{cm} \mathrm{H} \mathrm{H}_{2} \mathrm{O} / \mathrm{L} / \mathrm{s}\right)\end{array}$ & $\begin{array}{l}\text { Pore Size } \\
\quad(\mu \mathrm{m})\end{array}$ \\
\hline Anest-Guard & Electrostatic: hydrophobic polypropylene & 50 & 1.1 & $>0.3$ \\
\hline Iso-Gard HEPA Light & HEPA mechanical: hydrophobic glass fibers & 80 & 2.0 & $<0.3$ \\
\hline ServoDuo Guard & $\begin{array}{l}\text { HEPA mechanical and electrostatic: hydrophobic } \\
\text { glass fibers }\end{array}$ & 170 & 1.5 & $<0.3$ \\
\hline Humid-Vent Compact & $\begin{array}{l}\text { HME filter and electrostatic: hydrophobic } \\
\text { polypropylene and hygroscopic condensing paper } \\
\text { media }\end{array}$ & 38 & 1.8 & $>0.3$ \\
\hline Avea Internal heated HEPA & HEPA mechanical & $>200$ & 1.75 & $<0.3$ \\
\hline \multicolumn{5}{|c|}{$\begin{array}{l}\text { * Manufacturer data. Filter pore size is imprecise and not always provided by the manufacturer; the values shown are estimates, except for the Avea internal heated filter. Despite this imprecision, all } \\
\text { the studied filters can stop most nebulized drugs (particle mean diameter usual range } 2-5 \mu \mathrm{m} \text { ). However, these filters' effective filtration surfaces differ greatly, depending at least on the filter } \\
\text { internal volume. } \\
\text { HEPA = high-efficiency particulate air filter }\end{array}$} \\
\hline
\end{tabular}

\section{Ventilator Circuits}

We used the following circuits:

- Corrugated unheated circuit (used with the MR460 heated humidifier): no heating of either the inspiratory or expiratory limb; due to condensation, a water trap on each limb is mandatory.

- Mono-heated circuit (RT212): only the inspiratory limb is heated, by a wire; the occurrence of condensation within the expiratory limb requires a water trap.

- Older-generation bi-heated circuit (RT100), no water trap: both the inspiratory and expiratory limbs are heated.

- Newer-generation bi-heated circuit (Evaqua, RT340), no water trap: both inspiratory and expiratory limbs are heated, and it minimizes condensate in the expiratory limb by allowing water vapor to diffuse through the tubing wall.

In all cases, breathing systems and filters were kept horizontal to avoid drainage of the expiratory limb into the filter or into the test lung.

\section{Filter Resistance Measurements}

Resistance was measured ex vivo, using a heated-wire pneumotachograph and a differential pressure transducer (PF302, IMT, Buchs, Switzerland). Differential pressures were measured before experimental procedures (dry filter) and after 24 hours under each condition, progressively increasing gas flow through the device from 10 to $100 \mathrm{~L} /$ min. If consistent, differential pressures measured at 30 , 60 , and $90 \mathrm{~L} / \mathrm{min}$ were computed to calculate filter resistance. Measures were performed at constant room temperature $\left(21^{\circ} \mathrm{C}\right)$. Same measurements were also performed

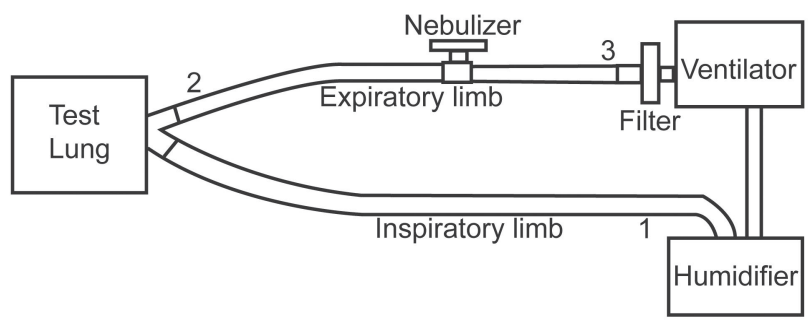

Fig. 1. Experimental bench test. An Evita 2 Dura ventilator was used for most measurements, except for the internal heated filter testing. Nebulization was performed on the expiratory limb, to enhance particle deposition on the filter. Hygrometric measurements were performed at 3 locations: 1 : inspiratory limb; 2: expiratory limb, immediately after the Y-piece; 3 : expiratory limb, immediately before the ventilator input. The circuit and filter were kept horizontal to avoid drainage of the expiratory limb into the filter or into the test lung.

using a bi-heated circuit (RT100), but without nebulization. At least 4 different measures were performed for each filter and condition.

Several measurements were performed in vivo at the bedside, while retrieving filters after clinical use.

\section{Hygrometry}

Hygrometric measurements were performed after 3 hours for each breathing system, in 3 different locations (inspiratory limb before the Y-piece, expiratory limb after the Y-piece, and expiratory limb before the ventilator input, Fig. 1), using the psychrometric method. ${ }^{19,20}$ Three measurements were recorded for each circuit. Results are expressed as absolute humidity and relative humidity of delivered gases. These results were performed to ensure appropriateness of the experimental model. 
Table 2. Ex-Vivo Resistance Measurements After 24 Hours of Use

\begin{tabular}{|c|c|c|}
\hline Circuit & Filter & $\begin{array}{c}\text { Flow Resistance } \\
\text { mean } \pm \mathrm{SD} \\
\left(\mathrm{cm} \mathrm{H}_{2} \mathrm{O} / \mathrm{L} / \mathrm{s}\right)\end{array}$ \\
\hline \multirow[t]{5}{*}{ Baseline } & Anest-Guard (electrostatic) & $1.3 \pm 0.1$ \\
\hline & Humid-Vent (HME filter) & $2.3 \pm 0.1$ \\
\hline & Iso-Gard (standard HEPA) & $2.3 \pm 0.1$ \\
\hline & Servo Duo Guard (specific unheated HEPA) & $1.4 \pm 0.1$ \\
\hline & Avea (internal heated HEPA) & $0.6 \pm 0.1$ \\
\hline \multirow{5}{*}{$\begin{array}{l}\text { MR460 } \\
\text { Unheated }\end{array}$} & Anest-Guard (electrostatic) at $10 \mathrm{~h}^{*}$ & NA \\
\hline & Humid-Vent (HME filter) at $6 \mathrm{~h}^{*}$ & NA \\
\hline & Iso-Gard (standard HEPA) at $19 \mathrm{~h}^{*}$ & NA \\
\hline & Servo Duo Guard (specific unheated HEPA) at $19 \mathrm{~h}^{*}$ & NA \\
\hline & Avea (internal heated HEPA) & $0.7 \pm 0.1$ \\
\hline \multirow{5}{*}{$\begin{array}{l}\text { RT212 } \\
\quad \text { Mono-heated }\end{array}$} & Anest-Guard (electrostatic) & $2.4 \pm 0.1$ \\
\hline & Humid-Vent (HME filter) at $20 \mathrm{~h}^{*}$ & NA \\
\hline & Iso-Gard (standard HEPA) & $3.1 \pm 0.1$ \\
\hline & Servo Duo Guard (specific unheated HEPA) & $1.7 \pm 0.1$ \\
\hline & Avea (internal heated HEPA) & $0.5 \pm 0.1$ \\
\hline \multirow{5}{*}{$\begin{array}{l}\text { RT100 } \\
\quad \text { Old bi-heated }\end{array}$} & Anest-Guard (electrostatic) & $1.3 \pm 0.1$ \\
\hline & Humid-Vent (HME filter) at $24 \mathrm{~h} *$ & NA \\
\hline & Iso-Gard (standard HEPA) & $2.6 \pm 0.1$ \\
\hline & Servo Duo Guard (specific unheated HEPA) & $1.5 \pm 0.1$ \\
\hline & Avea (internal heated HEPA) & $0.6 \pm 0.1$ \\
\hline \multirow{5}{*}{$\begin{array}{l}\text { RT340 } \\
\text { New bi-heated }\end{array}$} & Anest-Guard (electrostatic) & $1.3 \pm 0.1$ \\
\hline & Humid-Vent (HME filter) & $2.3 \pm 0.1$ \\
\hline & Iso-Gard (standard HEPA) & $2.1 \pm 0.1$ \\
\hline & Servo Duo Guard (specific unheated HEPA) & $1.5 \pm 0.1$ \\
\hline & Avea (internal heated HEPA) & $0.7 \pm 0.1$ \\
\hline \multirow{5}{*}{$\begin{array}{l}\text { RT100 } \\
\text { No nebulization }\end{array}$} & Anest-Guard (electrostatic) & $1.2 \pm 0.1$ \\
\hline & Humid-Vent (HME filter) & $2.2 \pm 0.1$ \\
\hline & Iso-Gard (standard HEPA) & $1.9 \pm 0.1$ \\
\hline & Servo Duo Guard (specific unheated HEPA) & $0.9 \pm 0.1$ \\
\hline & Avea (internal heated HEPA) & $0.6 \pm 0.1$ \\
\hline \multicolumn{3}{|c|}{$\begin{array}{l}\text { *Sequence interrupted because of occlusion at } t \\
\text { HME }=\text { heat-and-moisture exchanger } \\
\text { HEPA = high-efficiency particulate air filter } \\
\text { NA = not applicable }\end{array}$} \\
\hline
\end{tabular}

\section{Statistical Analysis}

Analysis was performed using statistics software (StatView 5.0, SAS Institute, Cary, North Carolina). Values are given as individual values and/or mean $\pm \mathrm{SD}$. A box and whiskers plot figure was used to compare the overall resistance values for each filter, assuming a $20 \mathrm{~cm} \mathrm{H}_{2} \mathrm{O} / \mathrm{L} / \mathrm{s}$ resistance value when occlusion occurred. Data were compared using non-parametric KruskallWallis and Mann-Whitney tests for independent variables. A $P<.05$ was considered statistically significant.

\section{Results}

\section{Resistance}

The filter resistance measurements are shown in Table 2. Measurement ended prematurely because of occlusion in
3 filters with unheated circuits: at 6 hours with the HME filter, at 10 hours with the electrostatic filter, and at 19 hours with the standard HEPA filter. Measurements had to be performed at 19 hours with the specific HEPA filter with unheated circuit, because of water level exceeding the tolerated limit, but without occlusion signs. HME filter had occlusion prior to 24 hours with the unheated, mono-heated, and older-generation bi-heated circuit. With the newergeneration bi-heated circuits, no significant resistance increase was observed at 24 hours, whatever the filter type.

The in vivo measurements are shown in Table 3. No significant resistance increase was observed. However, no unheated circuits nor electrostatic or HME filters were used with patients. The internal heated HEPA filter had no significant resistance increase, even after more than 3 months of use. 
Table 3. In-Vivo Differential Pressure Measurements*

\begin{tabular}{|c|c|c|c|c|}
\hline \multirow[b]{2}{*}{ Circuit } & \multirow[b]{2}{*}{ Filter } & \multicolumn{3}{|c|}{ Differential Pressure $\left(\mathrm{cm} \mathrm{H}_{2} \mathrm{O}\right)$} \\
\hline & & $\begin{array}{l}\text { at } 30 \\
\mathrm{~L} / \mathrm{min}\end{array}$ & $\begin{array}{l}\text { at } 60 \\
\mathrm{~L} / \mathrm{min}\end{array}$ & $\begin{array}{l}\text { at } 90 \\
\mathrm{~L} / \mathrm{min}\end{array}$ \\
\hline \multirow{6}{*}{ RT100 } & Servo Duo Guard (specific HEPA) at $24 \mathrm{~h}$ & 0.60 & 1.00 & 1.64 \\
\hline & Servo Duo Guard (specific HEPA) at $48 \mathrm{~h}$ & 0.61 & 1.29 & 2.19 \\
\hline & Servo Duo Guard (specific HEPA) at $72 \mathrm{~h}$ & 0.57 & 1.21 & 2.07 \\
\hline & Iso-Gard (standard HEPA) at $24 \mathrm{~h}$ & 0.93 & 1.94 & 2.98 \\
\hline & Iso-Gard (standard HEPA) at $48 \mathrm{~h}$ & 0.92 & 1.87 & 3.43 \\
\hline & Iso-Gard (standard HEPA) at $72 \mathrm{~h}$ & 0.87 & 1.94 & 3.41 \\
\hline \multirow[t]{5}{*}{ RT340 } & Servo Duo Guard (specific HEPA) at $24 \mathrm{~h}$ & 0.70 & 1.48 & 2.46 \\
\hline & Humid-Vent (HME filter) at $24 \mathrm{~h}$ & 0.99 & 2.10 & 3.52 \\
\hline & Anest-Guard (electrostatic) at $24 \mathrm{~h}$ & 0.61 & 1.29 & 2.1 \\
\hline & Avea (internal heated HEPA) J86 & 0.16 & 0.41 & 0.74 \\
\hline & Avea (internal heated HEPA) J5 + colimycine 6 million $\times 5$ & 0.46 & 0.92 & 1.53 \\
\hline
\end{tabular}

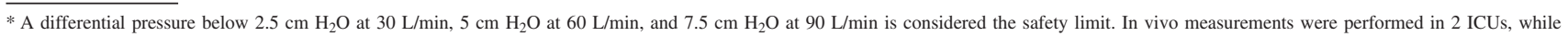
such expiratory limb protection was performed for clinical purpose. No measurements crossed the safety limit.

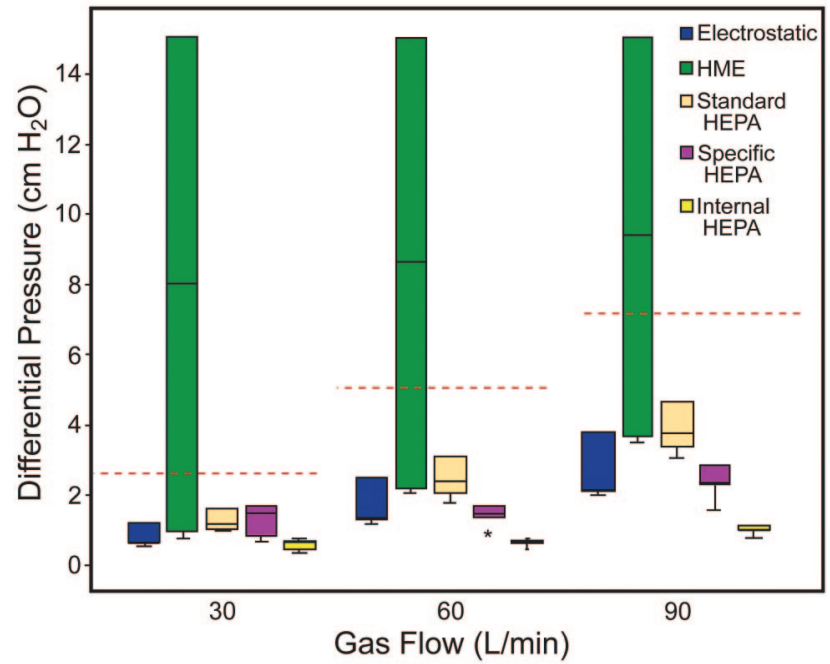

Fig. 2. Pressure at 3 gas flows. The red dashed lines depict the safety limit under each flow condition. A flow resistance of $5 \mathrm{~cm} \mathrm{H}_{2} \mathrm{O} / \mathrm{L} / \mathrm{s}$ implies a pressure difference of $5 \mathrm{~cm} \mathrm{H}_{2} \mathrm{O}$ at a flow of $60 \mathrm{~L} / \mathrm{min}$, and may be considered the safety limit. Given the presumed linear relationship between pressure and flow, the differential pressure limits at $30 \mathrm{~L} / \mathrm{min}$ and $90 \mathrm{~L} /$ min are assumed to be $2.5 \mathrm{~cm} \mathrm{H}_{2} \mathrm{O}$ and $7.5 \mathrm{~cm} \mathrm{H}_{2} \mathrm{O}$, respectively. By convention, a $20 \mathrm{~cm} \mathrm{H}_{2} \mathrm{O}$ value was considered when occlusion was experienced. At all flows, a statistical difference $(P<.001)$ was observed for heat-and-moisture exchanger (HME) filter and the internal high-efficiency particulate air (HEPA) devices, as compared to the other filter types. In all cases, the differential pressure values crossed the safety limit with the HME filter.

Figure 2 illustrates the median differential pressure values for each filter type at the 3 different gas flows.

\section{Impact of Nebulization}

Nebulization did not seem to have a great impact on resistance to flow, except for the HME filter, which suffered occlusion prior to 24 hours with nebulization.

\section{Hygrometry}

The main differences between circuits were observed at the ventilator expiratory input (location of the filter). Relative humidity tended to differ when considering circuits with unheated expiratory limbs and those with heated expiratory limbs (Table 4).

\section{Discussion}

This experimental bench study confirms that expiratory limb filtration may induce several major adverse events, such as experienced in previous clinical studies. ${ }^{10,21}$ The increase in the resistance of an expiratory filter over time is due mainly to the humidification circuit type, rather than to nebulization. If expiratory limb filtration is mandatory during mechanical ventilation, it may require the use of specifically dedicated filtering devices, and/or heated expiratory limbs. The HME filter should never be used for such purpose, as obstruction is to be expected. Though expiratory filter obstruction related to nebulization may be less common and predictable, clinicians should remain aware of that hazard.

When using an expiratory filter to protect healthcare workers from airborne contaminants, it is mandatory to consider the filter's efficiency. Depending on the device type and the specific particles size, certain devices might be inefficient. ${ }^{1}$ In fact, filtration efficiency is extremely variable, and manufacturers' tests are often misleading. ${ }^{1,11,22}$ Guidelines that were produced after the SARS outbreak recommended the use of "submicron filters."7,9 Within the Canadian guidelines, the authors recommended the constant use of a heated expiratory HEPA filter. ${ }^{8}$ Taking into account our results and routine prac- 
Table 4. Hygrometric Measurements*

\begin{tabular}{|c|c|c|c|c|c|c|c|c|c|c|c|c|}
\hline & \multicolumn{4}{|c|}{ Inspiratory $\dagger$} & \multicolumn{4}{|c|}{ Expiratory $1 \neq$} & \multicolumn{4}{|c|}{ Expiratory $2 \S$} \\
\hline & $\begin{array}{l}\text { MR460 } \\
\text { Unheated }\end{array}$ & $\begin{array}{c}\text { RT212 } \\
\text { Mono-heated }\end{array}$ & $\begin{array}{c}\text { RT100 } \\
\text { Old } \\
\text { bi-heated }\end{array}$ & $\begin{array}{c}\text { RT340 } \\
\text { New } \\
\text { bi-heated }\end{array}$ & $\begin{array}{l}\text { MR460 } \\
\text { Unheated }\end{array}$ & $\begin{array}{l}\text { RT212 } \\
\text { Mono- } \\
\text { heated }\end{array}$ & $\begin{array}{c}\text { RT100 } \\
\text { Old } \\
\text { bi-heated }\end{array}$ & $\begin{array}{c}\text { RT340 } \\
\text { New } \\
\text { bi-heated }\end{array}$ & $\begin{array}{l}\text { MR460 } \\
\text { Unheated }\end{array}$ & $\begin{array}{c}\text { RT212 } \\
\text { Mono-heated }\end{array}$ & $\begin{array}{c}\text { RT100 } \\
\text { Old } \\
\text { bi-heated }\end{array}$ & $\begin{array}{c}\text { RT340 } \\
\text { New } \\
\text { bi-heated }\end{array}$ \\
\hline $\begin{array}{l}\text { Absolute Humidity, } \\
\mathrm{mg} \mathrm{H}_{2} \mathrm{O} / \mathrm{L}\end{array}$ & $44.6 \pm 1.4$ & $39.3 \pm 0.1$ & $39.0 \pm 0.6$ & $39.3 \pm 0.1$ & $33.5 \pm 1.4$ & $33.3 \pm 0.4$ & $32.7 \pm 1.1$ & $33.0 \pm 0.8$ & $22.2 \pm 1.4$ & $21.9 \pm 0.3$ & $33.8 \pm 1.0$ & $24.1 \pm 0.6$ \\
\hline Relative Humidity, \% & $86.5 \pm 1.1$ & $100 \pm 2.6$ & $83.2 \pm 4.5$ & $86.7 \pm 2.1$ & $99.1 \pm 1.6$ & $97.5 \pm 2.0$ & $96.8 \pm 1.0$ & $99.1 \pm 1.1$ & $100 \pm 1.4$ & $95.3 \pm 2.7$ & $54.6 \pm 3.8$ & $71.1 \pm 1.7$ \\
\hline \multicolumn{13}{|c|}{$\begin{array}{l}\text { Values are mean } \pm \text { SD. } \\
* \text { There are no statistically significant differences. }\end{array}$} \\
\hline
\end{tabular}

tice, an internal heated HEPA filter seems to be adequate, allows prolonged ventilation without increasing expiratory circuit resistance, and thus does not require routine daily changes. However, an internal HEPA filter is standard in only half the critical care ventilators on the North American market. ${ }^{9}$ Moreover, the addition of an external heated HEPA filter may not be adequate, because such a fitting is not standardized and condensation can occur within the unheated final part of the circuit. On the contrary, most unheated HEPA filters have to be changed daily, resulting in potential healthcare worker exposure.

An increase in expiratory circuit resistance might induce intrinsic PEEP and dynamic hyperinflation. This potential adverse event is similar to what has been previously described when using an HME filter on the inspiratory limb, ${ }^{23,24}$ and it is presumed to be directly proportional to resistance increase. Those changes in ventilator mechanics might have dramatic consequences during lungprotective ventilation, which is mandatory in severe ARDS, as encountered during the SARS outbreak or the H1N1 flu pandemic.5,25-30

In a recent clinical trial of antibiotics nebulization, obstruction of the expiratory filter occurred in 3 patients of a 20-patient cohort, and caused cardiac arrest in 1 patient. ${ }^{21}$ Our results suggest that the increase in expiratory resistance is due mainly to filter saturation by water condensates. That finding is relevant to hygrometric measurements at the distal end of the expiratory limb. In a circuit with an unheated expiratory limb, the relative humidity is close to $100 \%$, resulting in high condensation on the filter. That high relative humidity is related to the low gas temperature at that location. A heated filter may prevent that condensation. Maintaining high expiratory gas temperature with a bi-heated circuit lowers the relative humidity and therefore decreases condensation and the related pressure increase from the filter. The absolute humidity at the distal expiratory end of the older-generation bi-heated circuit was higher than that in the newer-generation circuit. This absolute humidity value in the circuit with an unheated expiratory limb reduces as it enters a cooler circuit, which may be responsible for condensation. In this specific case the amount of condensation will vary with ambient temperature, so the level of condensation will vary.

The absolute humidity drop at the distal end of the expiratory limb with the newer-generation bi-heated circuit is explained by the specific design of the circuit, allowing water vapor to diffuse through the tubing wall. Therefore, such absolute humidity drop may not generate condensation due to such design.

Water condensates with the unheated circuit resulted in a major and rapid resistance increase with most of the filters, except with the internal heated HEPA filter. The resistance increase with the specific unheated HEPA filter did not exceed the $5 \mathrm{~cm} \mathrm{H}_{2} \mathrm{O} / \mathrm{L} / \mathrm{s}$ limit at $60 \mathrm{~L} / \mathrm{min}$; however, the measurements had to be performed after 19 hours because the water level was above the tolerated limit.

The $5 \mathrm{~cm} \mathrm{H} \mathrm{H}_{2} \mathrm{O} / \mathrm{L} / \mathrm{s}$ resistance limit was chosen because it was advocated in the 1992 international standard for HME filters (International Organization for Standardization draft standard 9360-1), ${ }^{31,32}$ though it no longer appeared in the second edition. ${ }^{33}$ Whereas expiratory limb heating is not a standard with all humidifiers, such condition may render heated expiratory filtration mandatory.

With the newer-generation bi-heated circuit (allowing humidity perspiration through the expiratory limb), humidification tended to increase expiratory limb resistance, at least while using the HME filter, but none of the encountered values exceeded the $5 \mathrm{~cm} \mathrm{H}_{2} \mathrm{O} / \mathrm{L} / \mathrm{s}$ limit. Such technical consideration could be important if expiratory limb filtration is mandatory and if no ventilator with internal heated filter is available.

Intermittent occlusion signs were observed in most conditions with the electrostatic filter, except with the newergeneration bi-heated circuit, due to water flush. The lower filtration properties of such filters, associated with such a potential adverse event, should make the clinician avoid its use, at least when airborne contaminant filtration is mandatory. If no internal heated filter is available and no newer-generation circuit is used, the specific unheated HEPA filter seems to be indicated, since its design mini- 
mizes the risk of sudden increase in expiratory resistance by water flush. In no condition should the HME filter be used, due to the potential risk of major resistance increase with most circuits.

Occlusion correlates with the effective filtration surface, which varies greatly from one device to the other (depending in part on the filter's internal volume): the greater the filtration surface, the lower the occlusion risk.

Nebulized colimycine is used as an alternative antibacterial measure in some ICUs. It was chosen in our study to test the impact of nebulization on expiratory resistance, whereas it is probably one of the products most likely to induce ventilator transducer dysfunction when unprotected, given its "stickiness" when nebulized. Moreover, this drug specifically needs to be nebulized using an ultrasonic or piezoelectric nebulizer, thus also increasing expiratory particle fraction. In our experimental setting the nebulizer was placed immediately after the Y-piece on the expiratory limb, to artificially maximize filter deposition. However, while comparing expiratory resistance with the older-generation bi-heated circuit, no direct consequence of nebulization was found in most cases, except when using the HME filter. If one could consider that the use of colimycine just adds another variable to the system, we conclude that in such condition, the major determinant of expiratory filter resistance is the humidification system, rather than nebulization itself. The HME filter should never be used for expiratory limb protection.

Like all experimental bench test studies, this one suffers several limitations. First, the results that were obtained with such an experimental setting may not reproduce what is observed in the real-life situation. Such limitation is accurate, especially because we enhanced particle deposition in the expiratory limb and because the test lung may by itself modify expiratory humidity values. However, the few in vivo measurements that were performed within this study seemed to corroborate our main findings; psychrometric values tended to fit values that were previously observed within several clinical trials ${ }^{19}$; and we tried to standardize the climate conditions in the experiment room.

Second, if the filters we used represented the main available filter types, one may also consider that filters from different manufacturers may behave differently. ${ }^{19,31}$ Different circuits or humidifiers may also lead to different results. Our results, however, seemed to fairly depict the different clinical situations that may be encountered when associating expiratory filtration with active heated humidification.

Third, our experimental settings did not allow the test lung to "expire" water vapor, to mimic a real patient. If this point is considered as a major limitation, psychrometric measurements performed just before the filter reproduced standard humidification values that limit such a criticism.
Fourth, given the difficulty of standardization and length of the experimental measurements, only one set of 4 values is reported for each filter type and condition. Several measurements were performed under the same conditions to ensure the internal validity and reproducibility of the model. Due to the fact that measurements were highly time-consuming, such multiple measurements were not performed in all cases.

Last, our suggestion that nebulization plays a lesser role in obstruction of the expiratory filter may be limited to the substance and dose evaluated in the study.

\section{Conclusions}

In conclusion, this study confirms the major impact of active humidification on the resistance on unheated expiratory filters. Nebulization by itself does not seem to be the primary determinant in expiratory limb resistance increase, except perhaps while using the HME filter and specific types of circuits. Such deleterious consequences may, however, be limited when using a bi-heated (especially newer-generation) circuit, thus allowing maintenance of filtering devices for at least 24 hours. With an unheated circuit, only an internal heated HEPA filter should be used, to avoid circuit occlusion. HME filters should never be used for expiratory limb protection, given their rapid occlusion and the impact of nebulization particles on their resistance.

\section{REFERENCES}

1. Demers RR. Bacterial/viral filtration: let the breather beware! Chest 2001;120(4):1377-1389.

2. Palmer LB, Smaldone GC, Simon SR, O'Riordan TG, Cuccia A. Aerosolized antibiotics in mechanically ventilated patients: delivery and response. Crit Care Med 1998;26(1):31-39.

3. Wilkes AR. Heat and moisture exchangers and breathing system filters: their use in anaesthesia and intensive care. Part 2: practical use, including problems, and their use with paediatric patients. Anaesthesia 2011;66(1):40-51.

4. American Academy of Pediatrics Committee on Infectious Diseases. Ribavirin therapy of respiratory syncytial virus. Pediatrics 1987; 79(3):475-478.

5. Recommandations des experts de la Société de Réanimation de Langue Française. Prévention de la transmission croisée en réanimation. Réanimation 2002;11(4):250-256. Article in French.

6. A. Mercat, J-C. Richard, A. Combes, J Chastre, JD Ricard, D Dreyfuss et al; on behalf of the REVA group. Prise en charge des forms graves du Syndrome de Détresse Respiratoire Aiguë liées au A (H1N1): en situation pandémique. http://www.sante.gouv.fr/IMG/ pdf/AREC-ECMO_fiche_DGS_LC.pdf. Accessed May 17, 2013. Article in French.

7. Levy MM, Baylor MS, Bernard GR, Fowler R, Franks TJ, Hayden $\mathrm{FG}$, et al. Clinical issues and research in respiratory failure from severe acute respiratory syndrome. Am J Respir Crit Care Med 2005; 171(5):518-526.

8. McKeon S. Vancouver Coastal Health Guidelines for the use of respiratory equipment for patients on airborne or enhanced droplet 


\section{Impact of Humidification and Nebulization During Expiratory Limb Protection}

precautions in acute care facilities; 2009. http://www.csrt.com/en/ professional/pdf/Vancouver-Guidelines.pdf. Accessed May 17, 2013.

9. Thiessen RJ. The impact of severe acute respiratory syndrome on the use of and requirements for filters in Canada. Respir Care Clin N Am 2006;12(2):287-306.

10. Lawes EG. Hidden hazards and dangers associated with the use of HME/filters in breathing circuits. Their effect on toxic metabolite production, pulse oximetry and airway resistance. Br J Anaesth 2003; 91(2):249-264.

11. Thiessen RJ. Filtration of respired gases: theoretical aspects. Respir Care Clin N Am 2006;12(2):183-201.

12. Barton RM. Detection of expiratory antibacterial filter occlusion. Anesth Analg 1993;77(1):197.

13. Buckley PM. Increase in resistance of in-line breathing filters in humidified air. Br J Anaesth 1984;56(6):637-643.

14. Prados W. A dangerous defect in a heat and moisture exchanger. Anesthesiology 1989;71(5):804.

15. Prasad KK, Chen L. Complications related to the use of a heat and moisture exchanger. Anesthesiology 1990;72(5):958.

16. Schummer W, Schummer C, Fuchs J, Voigt R. Sudden upper airway obstruction due to invisible rain-out in the heat and moisture exchange filter. Br J Anaesth 2002;89(2):335-336.

17. Stacey MR, Asai T, Wilkes A, Hodzovic I. Obstruction of a breathing system filter. Can J Anaesth 1996;43(12):1276.

18. Davies JBS, Bromilow J. Bacterial filter obstruction with the use of ultrasonic nebulisation. Anaesthesia 2011;66(5):394-395.

19. Lellouche F, Taillé S, Lefrançois F, Deye N, Maggiore SM, Jouvet $\mathrm{P}$ et al; Groupe de Travail sur les Respirateurs de l'AP-HP. Humidification performance of 48 passive airway humidifiers: comparison with manufacturer data. Chest 2009;135(2):276-286.

20. Ricard JD, Le Mière E, Markowicz P, Lasry S, Saumon G, Djedaïni $\mathrm{K}$, et al. Efficiency and safety of mechanical ventilation with a heat and moisture exchanger changed only once a week. Am J Respir Crit Care Med 2000;161(1):104-109.

21. Lu Q, Yang J, Liu Z, Gutierrez C, Aymard G, Rouby JJ; on behalf of the Nebulized Antibiotics Study Group. Nebulized ceftazidime and amikavin in ventilator-associated pneumonia caused by Pseudomonas aeruginosa. Am J Respir Crit Care Med 2011;184(1):106115.

22. Medicines and Healthcare Products Regulatory Agency. An assessment of 104 breathing system filters. London: MHRA; 2004. http://
www.mhra.gov.uk/Publications/Safetywarnings/MedicalDeviceAlerts/ CON008573. Accessed May 17, 2013

23. Iotti GA, Olivei MC, Braschi A. Mechanical effects of heat-moisture exchangers in ventilated patients. Crit Care 1999;3(5):R77-R82.

24. Iotti GA, Olivei MC, Palo A, Galbusera C, Veronesi R, Comelli A, et al. Unfavorable mechanical effects of heat and moisture exchangers in ventilated patients. Intensive Care Med 1997;23(4):399-405.

25. Chiumello D, Marino A, Lazzerini M, Caspani ML, Gattinoni L. Lung recruitability in ARDS H1N1 patients. Intensive Care Med 2010;36(10):1791-1792.

26. Jaber S, Conseil M, Coisel Y, Jung B, Chanques G. [ARDS and influenza A (H1N1): patients' characteristics and management in intensive care unit. A litterature review]. Ann Fr Anesth Reanim 2009;29(2):117-125. Article in French.

27. Davies A, Jones D, Bailey M, Beca J, Bellomo R, Blackwell N, et al; on behalf of the Australia and New Zealand Extracorporeal Membrane Oxygenation (ANZ ECMO) Influenza Investigators. Extracorporeal membrane oxygenation for 2009 influenza $A(H 1 N 1)$ acute respiratory distress syndrome. JAMA 2009;302(17):1888-1895.

28. Hui DS, Lee N, Chan PK. Clinical management of pandemic 2009 influenza A (H1N1) infection. Chest 2010;137(4):916-925.

29. The Acute Respiratory Distress Syndrome Network. Ventilation with lower tidal volumes as compared with traditional tidal volumes for acute lung injury and the acute respiratory distress syndrome. N Engl J Med 2000;342(18):1301-1308.

30. Richard JC, Girault C, Leteurtre S, Leclerc F; on behalf of the SRLF. Prise en charge ventilatoire du syndrome de détresse respiratoire aiguë de l'adulte et de l'enfant (nouveau-né exclu)—Recommandations d'Experts de la Société de Réanimation de Langue Française. Réanimation 2005;14:10. Article in French

31. Lucato JJ, Tucci MR, Schettino GP, Adams AB, Fu C, Forti G Jr, et al. Evaluation of resistance in 8 different heat-and-moisture exchangers: effects of saturation and flow rate/profile. Respir Care 50(5):636-643

32. Morgan-Hughes NJ, Mills GH, Northwood D. Air flow resistance of three heat and moisture exchanging filter designs under wet conditions: implications for patient safety. Br J Anaesth 2001;87(2): 289-291.

33. British Standards Institution. Anaesthetic and respiratory equipment - heat and moisture exchangers (HMEs) for humidifying respired gases in humans. Part I: HME for use with minimum tidal volume of $250 \mathrm{~mL}$. BS EN ISO 9360-1:2009.

This article is approved for Continuing Respiratory Care Education credit. For information and to obtain your CRCE

(free to AARC members) visit

www.rcjournal.com

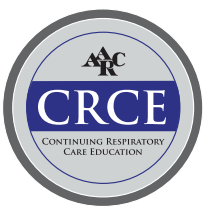

